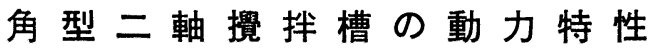

\author{
佐 藤一省・前田法 史* \\ 吉 野 善 彌 \\ 東京理科大学工学部 工業化学科
}

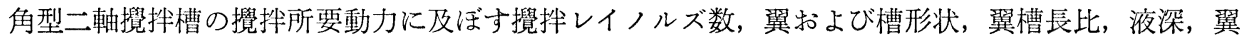
の相対的な回転方向などの影響を実験的に検討した．㩭挥所要動力はそれぞれの翼を中心とした一次 回転流の発達度合と密接な対応を示す．平羽根タービン翼を設置した場合の槽内の流れは幾何学的条 件によって一次回転流を主体とした流動パターンから二次循環流を主体とした流動パターンをで多様 な変化を示し, 動力数はそれに対応して 3 前後から 6 前後まで大きく変化する. 一方, 傾斜タービン 翼を設置した場合には，二次循環流を主体とした流動パターンを形成し，二軸間の相互干渉も注とん どなく，動力数はほぼ一定值を示す。
\end{abstract}

\section{緒言}

角型攪拌槽は敷地の有効利用や前後の装置との関連な どから利用されることが多いため, 槽の形状は状況に応 じて多様である.したがって，幾何学的条件が鹠拌特性 に及ぼす影響については充分検討して置く必要があ る ${ }^{1,2)}$. とくに，長方形槽の短辺と長辺の長さが大きく 異なる場合や液深が辺の長さに較べて浅い場合などで は，攪拌機の設置台数や設置位置などを適切に設計する 必要がある.

攪汼機を複数台設置した場合の槽内に打ける流れは, それぞれの粯汼翼によって引き起こされる流れが相互に 干渉し合い，一軸の場合とは大なり小なり異なった流れ となり，動力特性もそれに応じて変化する.

本研究では，角型槽に攪拌機を複数台設置した場合の 基礎的設計資料を得る目的で，まず，角型二軸攪挥槽を 対象に, 㩭拌所要動力に及ぼす䚌拌レイノルズ数, 翼お よび槽の形状, 翼槽長比, 液深, 翼の相対的な回転方向 などの影響を実験的に検討した。

\section{1. 実験装置および方法}

実験に使用した槽はアクリル樹脂製の長方形槽で，長 辺 $A$ と短辺 $B$ との比 $A / B$ は長辺の長さを変えること によって 1.0 2.7 の範囲で変化させた. 短辺の長さは $30 \mathrm{~cm}$ である. 攪拌機は, Fig. 1 亿示すように, 長方 形槽を長辺方向に二分したときに，それぞれの中央とな る位置に設置した。したがって，䚌拌軸間の距離は長辺 の長さ $A$ の $1 / 2$ である. 液深は短辺の長さに等しい 30 $\mathrm{cm}$ の場合を主として検討したが，液深の影響について

$+\mp 162$ 新宿区神楽坂 1-3

* 日立テクノエンジニアリング (株)
も若干の検討を行った.

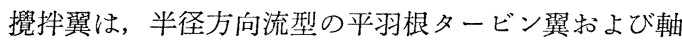
方向流型の傾斜タービン翼（下向流型）を用いた. 平羽 根タービン翼は翼長 $d$ を $5 \sim 15 \mathrm{~cm}$ の範困で変化させ たが，いずれの翼も羽根幅比 $b / d$, 羽根長比 $l / d$ はそれ ぞれ $1 / 5,1 / 4$ とし, 形状は相似とした. 傾斜タービン 翼は翼長 $d=7,15 \mathrm{~cm}$, 羽根幅比 $b / d=1 / 5$, 傾斜角度 45 度である. 羽根枚数はいずれも 6 枚である. 翼の設 置高さは液深の $1 / 3$ とした.

多軸攪汼槽においては，それぞれの翼の回転方向が問 題となるので，翼を同じ方向に回転させる場合と互いに 逆の方向に回転させる場合について検討を行った。

液には, 水あるいは水飴水溶液を使用し, 攪拌レイ, ルズ数 $R e$ を $R e=5 \times 10^{-1} \sim 10^{5}$ の範囲で変化させた.

鹠拌所要動力は抵抗線歪計型トルクピックアップ1)を 用いて測定した軸トルクと軸回転速度から算出した。 た，槽内に打ける流動パターンも適量投入したトレーサ 粒子の動きをスリット光を照射することによって観察な らびに写真撮影した.

なお，比較のために，二軸攪拌槽を長辺方向に二分し た場合の形状に相当する一軸㩭汼槽についても同様の実 験を行った.

\section{2. 実験結果および考察}

\section{$2 \cdot 1$ 攂拌レイノルズ数, 翼槽長比, 翼回転方向の影 響}

Fig. 2 は, 攪找所要動力を無次元化した動力数 $N_{p}$ と䚓抖レイノルズ数 $R e$ との関係を, 正方形槽に平羽根 タービン翼を一台設置した場合について，例示したもの である. 攪拌レイノルズ数が $10^{3}$ 以下の, いわゆる層流 域ならびに遷移域においては, 翼長 $d$ 之槽長 $B$ (正方形 

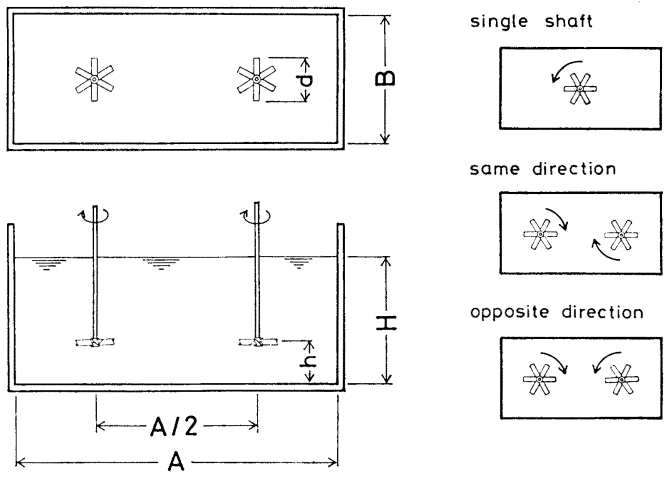

same direction

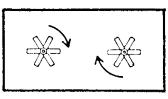

opposite direction

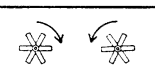

Fig. 1 Experimental apparatus

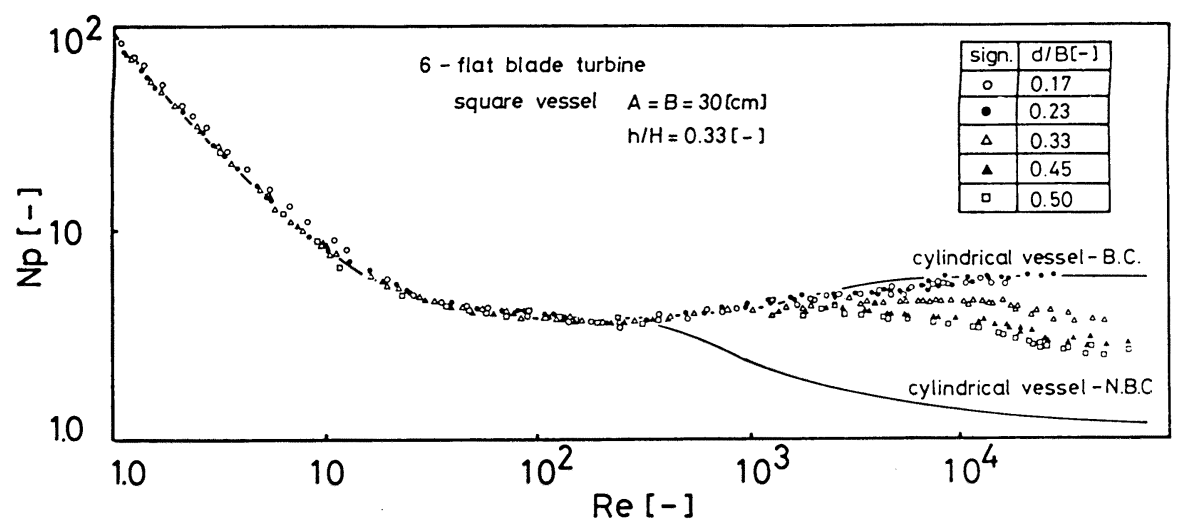

Fig. 2 Effect of impeller to vessel size ratio $d / B$ on the relations of power number $N_{p}$ and Reynolds number $R e$ in a square vessel

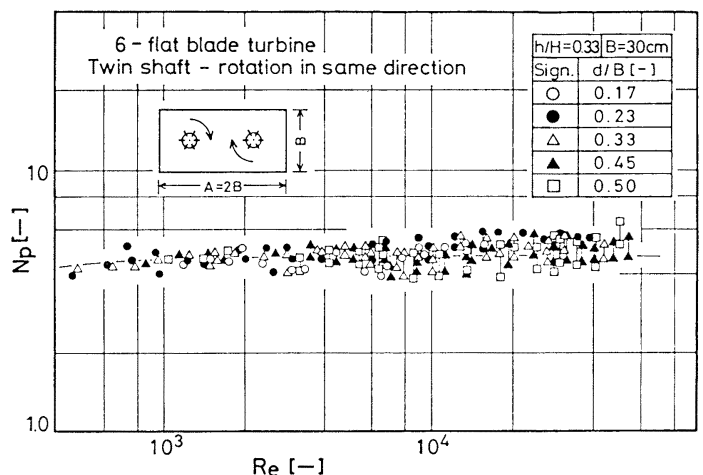

Fig. 3 Effect of impeller to vessel size ratio $d / B$ on the relations of power number $N_{p}$ and Reynolds number $R e$ in a twin shaft rectangular vessel $A / B=2.0$

一辺の長さ）との比, すなわち翼槽長比 $d / B$ の違いに よらず, 動力数は, 摫拌レイノルズ数に対してほぼ同一 の変化を呈するのに対して, 乱流域においては, 翼槽長 比によって異なった変化を示すことがわかる.

図中には比較のため同じ翼を円筒槽内で回転させた場

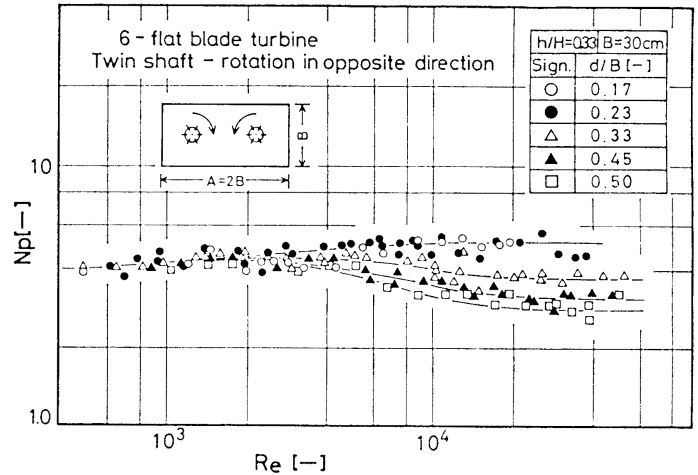

Fig. 4 Effect of impeller to vessel size ratio $d / B$ on the relations of power number $N_{p}$ and Reynolds number $R e$ in a twin shaft rectangular vessel $A / B$ $=2.0$

合の動力数も示してある. 図中 B.C. と記した実線は, 円筒槽に邪魔板を 4 枚 $(w / D=1 / 10)$ 設置した場合，また N.B.C. と記した実線は邪魔板を設置しない場合の結果 を示している. 円筒槽では, 乱流域に扣いても, 翼槽長 比による動力数の変化は, 本実験条件に 相当する $d / D$ 


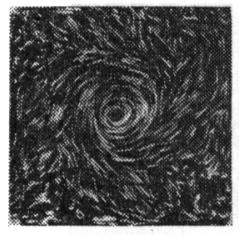

(a) $d / B=0.33$

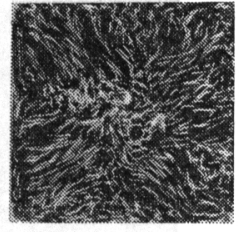

(b) $d / B=0.23$
Fig. 5 Flow pattern in a square vessel with a disc turbine $\left(R e=2.5 \times 10^{4}\right)$

$\leq 0.5$ の範囲では, ほとんど認められない22. しかし， 角型攪拌槽の攪拌所要動力以乱流域に拈いて $d / B$ の影 響をらける。

Figs. 3, 4 は長辺と短辺との比 $A / B$ が 2.0 の長方形 槽に平羽根タービン翼を二台設置した場合の動力特性を 例示したものである. 縦軸は攪汼機一台当りの動力数で ある. Fig. 3 は二台の攪汼機を同じ方向に回転させた 場合 (以下順回転攪拌と呼ぶ), Fig. 4 は互いに逆の方 向に回転させた場合（以下逆回転攪拌と呼ぶ）の結果を 示している.

乱流域に拈いては, 翼回転方向の違いによって, 動力 特性に明らかな相異が認められる. 順回転攪拌において は, 翼槽長比 $d / B$ によって, 動力数に傾向的な差異が 認められないのに対して, 逆回転攪拌においては, $d / B$ $=0.23 \sim 0.33$ を境にして, 翼長が相対的に大きくなる に従い動力数は低下する傾向を示す.

この長方形槽の中央の位置に仕切板を挿入すると, 幾 何学的には正方形槽に攪拌機を一台設置した場合に相当 するが，との状態に拈ける動力特性は Fig. 2 に示した と和りである. Fig. 2 を Fig. 4 と対比すると明らかな ように, 二軸逆回転攪拌に持ける攪汼機一台当りの動力 数は, 一軸正方形攪拌槽の場合と極めて類似した変化を 示し, 逆回転攪拌においては, 少なくとも動力特性で見 る限り, 攪拌機相互の干渉はさ核ど大さないことがわ かる. これに対して，二軸順回転藇拌の場合には，とく に翼槽長比が大きい条件下に执いて，一軸正方形攪汼槽 とは顕著な差異を示し，相互干渉の度合が大きいことを 示唆している. また, 二軸順回転摫汼の場合には, 流れ が不安定であることを反映して, 動力数の変動幅が大き くなっている*.

一軸正方形攪拌槽内に特ける流動パターンは, 平羽根 タービン翼の場合, 翼槽長比 $d / B=0.23 \sim 0.33$ を境に 大きく異なってくることは既に報告した1,2).すなわら, $d / B \geq 0.33$ の条件下では, Fig. 5 (a) に示すように, 一

* 二軸順回転摫汼の場合には，軸間中央近傍において流れが互いに向き 合う形となるため，それぞれの翼を中心とした二つの流れのバランス がくずれやすく，しばしば流れの対称性が大きく乱れ，これに応して 動力数にも変化が表れる. 変動幅は, Fig. 3 に例示したように, 平 均值の $10 \sim 20 \%$ 程度である. 二次循環流を主体とした流れとなる 条件のもとでは変動幅は小さい.

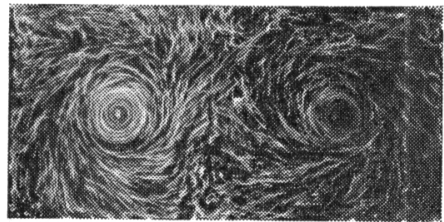

(a) Opposite direction

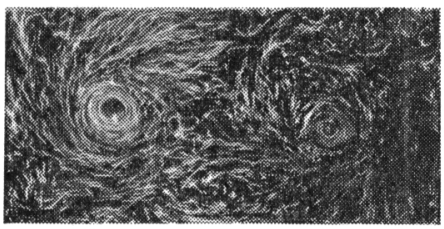

(b) Same direction

Fig. 6 Flow pattern in a rectangular vessel $A / B=2.0$ with twin disc turbines $\left(d / B=0.33, R e=2.5 \times 10^{4}\right)$

次回転流を主体とした流れとなり，翼の上下には，いわ ゆる固体的回転流が形成される. 一方 $d / B \leq 0.23$ の条 件下では, Fig. 5(b) に示すように, 上下方向の二次循 環流が相対的に強くなり，一次回転流は充分に発達でき ず，固体的回転流も形成されない。

前述の動力特性は, このよらな流れの特徴と密接な対 応を示している. 一軸正方形攪拌槽の $d / B \leq 0.23$ に打 ける動力数は, Fig. 2 に示したように, 流れが類似して いる邪魔板付円筒攪汼槽の動力数と洼注一致しているの に対して, $d / B$ がこれより大きくなると, 一次回転流の 発達に伴い動力数も低下してくる.

二軸攪拌槽の場合には，それぞれの翼が引き起こす流 れが大なり小なり相互に干渉し合らことになるが，相互 干渉の度合は翼槽長比だけではなく，翼の回転方向によ っても異なってくるので, 槽内の流れはさらに多様にな る.

$d / B \geq 0.33$ の条件下では, それぞれの翼が引き起こす 流れは一次回転流を主体としたものであるが，二軸逆回 転攪汼の場合には，Fig. 6(a) に示すように, 軸間にお いて相互の流れは並流の形となるため，相互干渉は弱 く, あたか子軸間中央の位置に固体壁が存在するかのよ らに, 一軸正方形攪拌槽内の流れと極めて類似したもの となる.これに対して, 二軸順回転攪汼の場合には,

Fig. 6(b) に示すように, 軸間に括いて回転の方向が相 互に向き合う形となるため，相互干渉が強く，それぞれ の翼を中心とした一次回転流は充分に発達せず, むしろ 上下方向の循環流が強い流れを形成することが認められ た.

翼槽長比が比較的小さい $d / B \leq 0.23$ の条件下に打い ては, 順回転攪拌, 逆回転攪拌いずれの場合にも, 一軸 


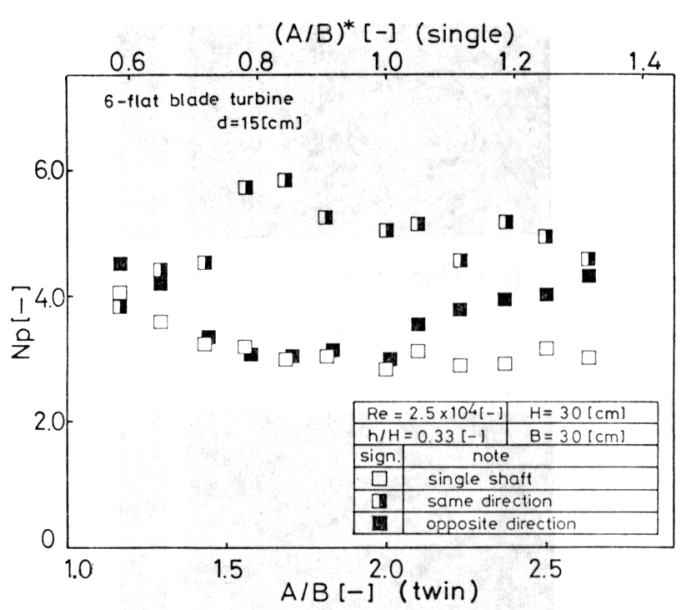

Fig. 7 Effect of side length ratio of vessel $A / B$ on power number $N_{p}$ of a disc turbine $(d / B=0.5)$

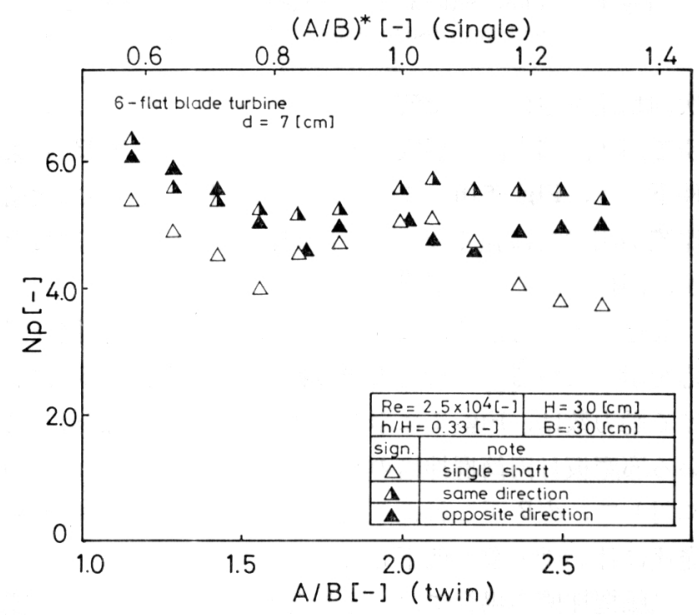

Fig. 8 Effect of side length ratio of vessel $A / B$ on power number $N_{p}$ of a disc turbine $(d / B=0.23)$

正方形攪拌槽の場合と同様に，それぞれの翼を中心とし た上下方向の二次循環流を主体とした流れとなる。この ため, 軸間叔ける流れの相互干渉はさほど強くない。 動力数にも翼回転方向の影響は認められず, 一軸正方形 攪拌槽の値に添涪一致した結果となっている.

以上は $A / B=2.0$ の槽形状に関する結果であるが, 槽 内に抢ける流れ拈よび動力特性は, 槽特よび翼の形状に よっても異なってくる.

\section{$2 \cdot 2$ 槽および翼形状の影響}

角型攪汼槽の攪拌所要動力は乱流域に打いて特徵的な 変化を示すことがわかったので，䚓找レイノルズ数が $R e=2.5 \times 10^{4}$ そ㧄いて, 槽㧊よび翼形状の影響を検討 した.

平羽根タービン翼については, 先にも述べたように, 翼槽長比 $d / B=0.23 \sim 0.33$ を境に槽内の流動パターン に顕著な差異が認められるため, 翼槽長比 $d / B=0.5$ と

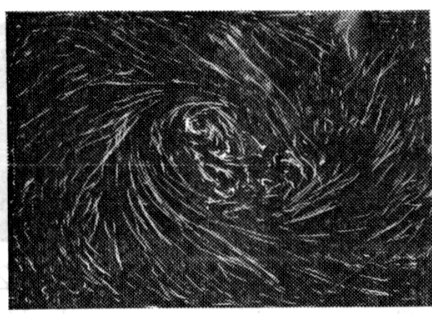

Fig. 9 Flow pattern in a rectangular vessel $A / B=1.4$ with twin disc turbines (same direction, $d / B=0.5$, $R e=2.5 \times 10^{4}$ )

0.23 の場合をそれぞれの代表例として動力数と $A / B$ と の関係を Figs. 7, 8 に示した. 二軸攪拌槽の軸間中央 の位置に仕切り板を插入すると相互干渉のない独立した 一軸攪拌槽となるが, その場合の測定結果を対応する $A / B$ の位置に $\square, \triangle$ 印で点経した. 上部横軸 $(A / B)^{*}$ は 対応する一軸攪拌槽の辺長比を表す.

翼槽長比が比較的に大きい場合には, Fig. 7 に示す ように, 翼回転方向の違いにより動力数に顕著な差が認 められる。

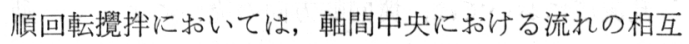
干渉が強いため, 動力数は一軸㩭拌槽の場合に較べ, 総 じて高い值を示す. $A / B$ を小さくして行くと，それに応 じて軸間距離が短くなるため, 相互干渉はしだいに強く なり, 動力数も徐々に増大する傾向を示す. しかし, $A / B=1.7$ 前後において動力数は極大となり, $A / B=1.5$ 前後に招いては動力数の急激な低下が認められる. $A / B$ が 1.5 以下に拈ける槽内の流れは先に述べた $A / B=2.0$ の場合とは大きく異なっている. 軸間中央に拈ける流れ は順回転㩭汼の場合には相互に向き合う形となるが，軸 間距離が小さくなると, Fig. 9 に示すように, 軸間中 央への液の流れ込みが抑制され, 槽壁に沿って槽内を一 巡する形の流動パターン，すなわちそれぞれの翼が形成 する流れが一つに合体し，二つの翼を内に包含する棈円 状の回転流となる.このため上下方向の循環流が弱くな り，動力数が減少するものと考光られる.

逆回転攪汼に和いては, 一軸攪拌槽内の流れに類似し た流れが形成され，動力数も順回転攪拌汇較べ，一軸覮 汼槽の場合に近い值となっている. しかし， $A / B$ が 2.0 以上になると動力数が徐々に増大し, 翼回転方向に上る 差異が小さくなってくることがわかる，槽内の流れは， $A / B$ の増大に伴い, 槽四隅からの反転流の方向が変化 し，それぞれの翼を中心とした一次回転流がしだいに抑 制され，上下方向の循環流を主体とした流れに移行して 行く.この流れの変化が動力数に反映したものと考兄ら れる.これに類似した現象は一軸攪汼槽においても確認 されている1). ただし，流動パターンならびに動力数の 変化は長辺と短辺との比がさらに大きい条件下 $\left((A / B)^{*}\right.$ 


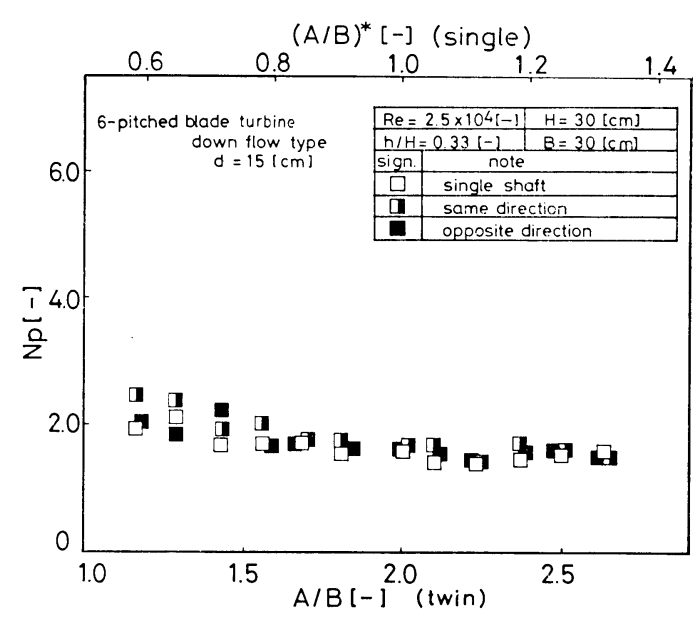

Fig. 10 Effect of side length ratio of vessel $A / B$ on power number $N_{p}$ of a pitched blade turbine $(d / B=0.5)$

$=1.6 \sim 1.7)$ において急激な形で起こり, 動力数は $d / B$ によらず 5.2 前後となる.

翼槽長比が小さくなると， Fig. 8 に示すように，動 力数は総体的に高くなるが， $A / B$ がごく小さい条件を除 けば，槽形状および翼回転方向による動力数の違いは $d / B=0.5$ の場合に較べて小さい，ただし，一軸攪拌槽 の動力数は，翼槽長比が大きい場合に較べて， $A / B$ によ る変化が顕著である. 先にも述べたように, 槽形状が正 方形に近い条件下，すなわち $(A / B)^{*}$ が $1.0 \sim 1.1$ の範 囲では，二次循環流を主体とした流動パターンを形成す るが， $(A / B)^{*}$ が 1.1〜1.4 の範囲では，一次回転流が 強まり, さらに, $(A / B)$ * が大きくなると再び二次循環 流を主体とした流れに移行する. 動力数は一次回転流が 強まると低下し, 二次循環流が主体となる条件下では増 大する傾向を示す.

二軸順回転攪拌では, 槽形状によらず一次回転流の形 成が抑制されるため動力数は高い值を示す. 二軸逆回転 では, $A / B=2.2 \sim 2.8$ (一軸鯢拌槽では一次回転流が強 まる範团 $(A / B)^{*}=1.1 \sim 1.4$ に対応する.）において， それぞれの翼を中心とした一次回転流が強まり, 動力数 が低下する.しかし，Fig. 7 に関連して述べた槽四隅 からの反転流の影響で一次回転流が充分には発達でき ず，動力数の低下はわずかである.

以上の結果から, 平羽根タービン翼を設置した場合に は, 槽内の流れは, 翼槽長比, 槽形状, 翼回転方向によ って，一次回転流を主体とした流動パターンから二次循 環流を主体とした流動パターンまで多様な変化を示すた め, 攪拌所要動力もそれに応じて， $N_{p}=3$ 前後から 6 前後まで大きく変化し，幾何学的条件の影響を強く受け ることがわかる.

一方, 傾斜タービン翼のような軸流型の翼を設置した

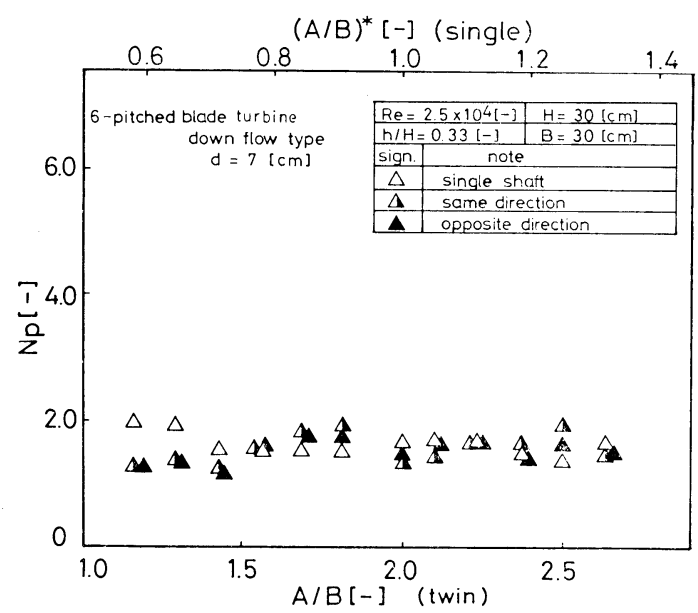

Fig. 11 Effect of side length ratio of vessel $A / B$ on power number $N_{p}$ of a pitched blade turbine $(d / B=0.23)$

場合には，上下方向の循環流を主体とした流れが形成さ れ，一次回転流の形成は抑制される. この場合の動力特 性は, Figs. 10, 11 に示すよらに, 平羽根タービン翼の 場合とは異なり，翼槽長比，槽形状，翼回転方向にほと んど依存せず, 動力数はほぼ一定值を示すことがわか る.

\section{$2 \cdot 3$ 液深の影響}

Figs. 12 15 は $A / B=2.0$ の槽形状における 動力数 と液深との関係を例示したものである. 翼の槽底からの 取付け高さはいずれの場合も液深の $1 / 3$ である.

平羽根タービン翼の場合には, 翼槽長比 $d / B$ によっ て液深の影響は異なってくる. 翼槽長比が比較的大きい $d / B=0.5$ においては, 一軸, 二軸攪拌いずれの場合に も, 液深が浅くなるにしたがい動力数は単調に減少す る. 二軸逆回転攪汼の動力数は液深によらず，一軸攪汼 槽の動力数にほぼ一致しているのに対して, 二軸順回転 攪挥の動力数はそれらに較べて高い值を示している. 二 軸順回転攪拌の二軸逆回転攪拌に対する動力数の比は, 液深が浅くなるほど大きくなっており，二軸順回転攪拌 時の相互干渉は液深が浅くなる汪ど強くなることがわか る。

翼槽長比が比較的小さい $d / B=0.23$ においては, 液 深によって槽内の流動パターンが変化し, 動力数もそれ に応じた変化を示す. $H / B$ が 1.0 前後では, 槽内は二 次循環流を主体とした流れを形成し, 動力数はいずれの 場合も5 前後の值を示すが, 液深が浅くなると, 一軸攪 拌槽では $H / B=0.85$, 二軸逆回転攪汼では $H / B=0.75$ を境に一次回転流を主体とした流れに移行する。ささに 液深を浅くすると，流れは再び， $H / B=0.5$ 前後に打い て，二次循環流を主体とした流れに変化する. $H / B=$ 0.35 以下では, 二軸順回転攪汼の場合も含めて, 一次 


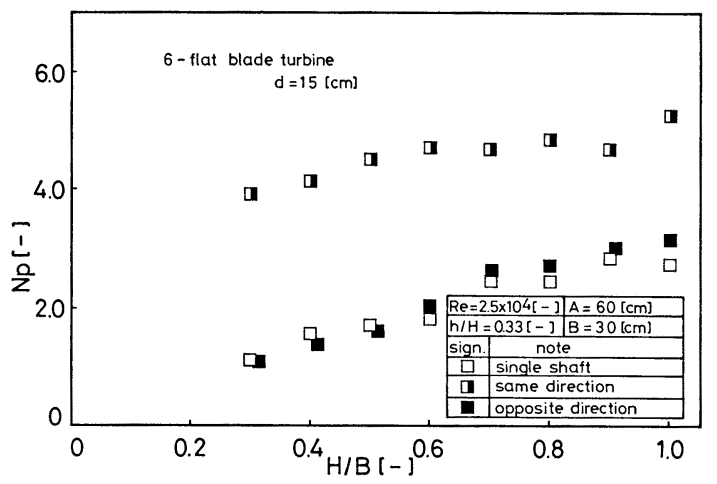

Fig. 12 Effect of liquid depth $H / B$ on power number $N_{p}$ of a disc turbine $(d \mid B=0.5)$

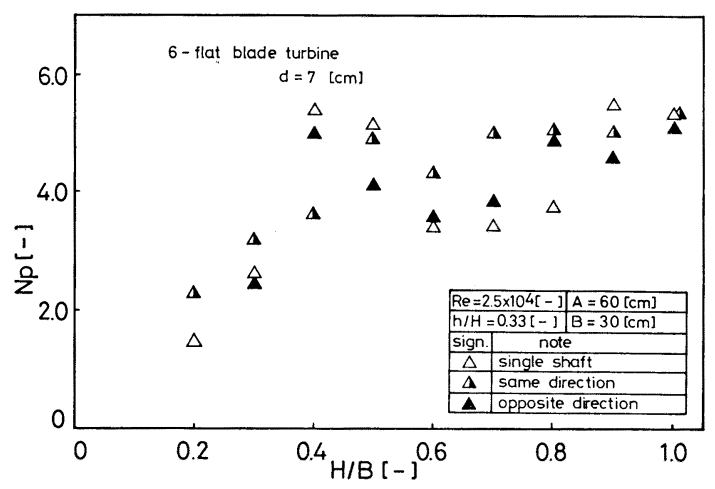

Fig. 13 Effect of liquid depth $H / B$ on power number $N_{p}$ of a disc turbine $(d / B=0.23)$

回転流を主体とした流れに移行し, 動力数は急激に減少 する. 二軸順回転攪挥の場合には， $H / B<0.35$ の範团 を除けば，いずれの液深に拄いても二次循環流を主体と した流れを形成し, 動力数もほぼ一定している. 一軸攪 拌槽および二軸逆回転攪拌の場合には, 一次回転流を主 体とした流れを形成する液深において動力数に低下が認 められる.

傾斜タービン翼の場合には, Figs. 14, 15 に示すよう に, $d / B=0.23, H / B=0.5 \sim 0.8$ 飞拈いて, 二軸逆回転 㩭汼掞よび一軸攪汼槽と二軸順回転攪汼との間に多小差 が認められるほかは, 翼回転方向の影響も少なく, $H / B$ $>0.4$ 以上の範囲においては, 液深に上る動力数の変化 も小さいことがわかる. 上下方向の循環流を主体とした 槽内の流孔が比較的に安定していることを示するのと考 えられる。

\section{結言}

角型二軸攪汼槽の攪拌所要動力に及ぼす攪拌レイノル ズ数, 槽および翼形状, 翼槽長比, 液深, 翼の相対的な 回転方向などの影響を, 槽内の流れとも対応させなが ら, 実験的に検討し,つぎの結果を得た。

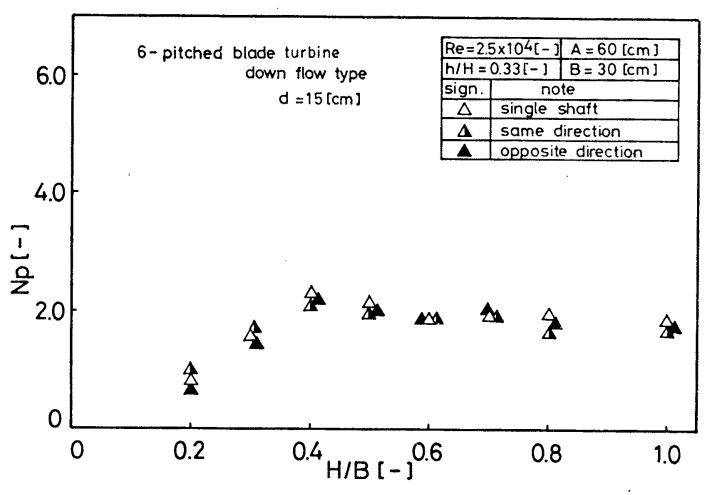

Fig. 14 Effect of liquid depth $H / B$ on power number $N_{p}$ of a pitched blade turbine $(d / B=0.5)$

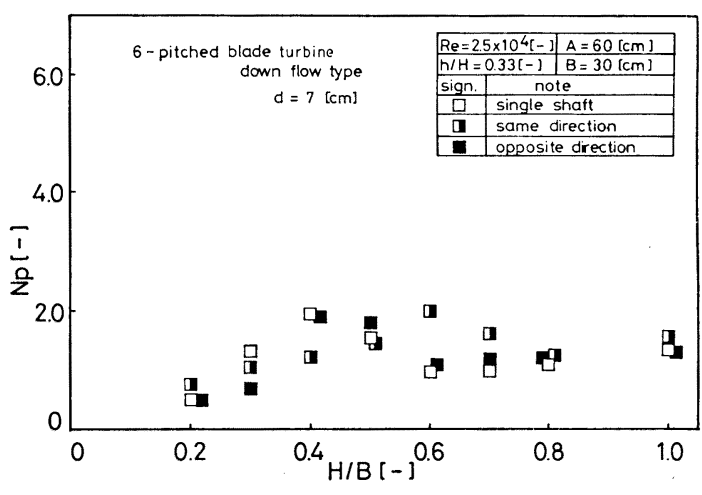

Fig. 15 Effect of liquid depth $H / B$ on power number $N_{p}$ of a pitched blade turbine $(d / B=0.23)$

1) 角型翼汼槽の攪拌所要動力はそれぞれの翼を中心 とした一次回転流の発達度合と密接な対応を示す.

2）平羽根タービン翼を設置した場合には，槽内の流 れは, 翼槽長比, 槽形状, 液深, 翼回転方向によって, 一次回転流を主体とした流動パターンから二次循環流を 主体とした流動パターンまで多様な変化を示すため, 動 力数も 3 前後から 6 前後まで大きく変化し, 幾何学的条 件の影響を強く受ける.

3）傾斜タービン翼を設置した場合には, 幾何学的条 件によらず，上下方向の循環流を主体とした流れが形成 されるため, 二軸間の相互干啮もほとんどなく, 動力数 はほぼ一定值を示す。

\section{Nomenclature}

$\begin{array}{rlr}A & =\text { side length of vessel } & {[\mathrm{m}]} \\ B & =\text { side length of vessel } & {[\mathrm{m}]} \\ b & =\text { blade wide of impeller } & {[\mathrm{m}]} \\ D & =\text { diameter of cylindrical vessel } & {[\mathrm{m}]} \\ d & =\text { diameter of impeller } & {[\mathrm{m}]} \\ H & =\text { depth of liquid } & {[\mathrm{m}]} \\ h & =\text { clearance between impeller and vessel } & \\ \text { bottom } & {[\mathrm{m}]}\end{array}$


$l=$ blade length of impeller

$N_{p}=$ power number of an impeller

$\operatorname{Re}=$ Reynolds number

$w \quad=$ wide of baffles [m]

[-]

[-]

[m]

\section{Literature cited}

1) Sato, K. and I. Inoue: Kagaku Kogaku Ronbunshu, 2, 160 (1976)

2) idem: Chem. Eng. Commun., 7, 45 (1980)

\title{
Power Consumption of Twin Impellers in Rectangular Stirred Vessels
}

\author{
Kazumi Sato, Norifumi Maeda* and Zenya Yoshino
}

Dept. of Ind. Chem., Science Univ. of Tokyo, Tokyo 162

Key Words: Agitation, Rectangular Stirred Vessel, Twin Impellers, Power Consumption, Flow Pattern

The effects of Reynolds number, configuration of impeller and vessel, ratio of impeller to vessel size, liquid depth and rotational direction of each impeller on power consumption of twin impellers in rectangular stirred vessels were examined experimentally.

Power consumption in the turbulent region was closely related to the degree of tangential flow to circulation flow formed by each impeller.

The flow pattern in a rectangular vessel with twin disc turbines varied with geometrical conditions from a pattern mainly composed of tangential flow to a pattern mainly composed of circulation flow. The power number in this system changed in the range of 3 to 6 corresponding to the change of flow pattern.

In the system of twin pitched-blade turbines, circulation flow was predominant. Therefore, interactions between impellers were weak and the power number remained nearly constant.

* Hitachi Techno Engineering Ltd., Tokyo 